\title{
Solar and Wind Energy: An Alternative Solution for the Problem of Jobless
} Economic Growth in Turkey

Güneş ve Rüzgar Enerjisi: Türkiye'deki Ístihdamsız Büyüme Sorunu Iç̧in Alternatif Bir Çözüm Yolu

Hüsnü BİLİR ${ }^{1}$

Article Info

Article History:

Date Submitted: 24.05.2019

Date Accepted: 01.08.2019

Jel Classification

Q42, Q 43, J08, J21.

Keywords:

Jobless economic growth, Renewable energy sources,

Solar energy,

Wind energy,

Employment opportunities

\begin{abstract}
Turkish economy has seen unemployment rates almost above $10 \%$ (and 20\% for youth) between 2006-2017, although it has grown 5,7\% on average in this period. The main reason of this "jobless economic growth" is Turkey's energy import dependency (which was 77,5\% in 2015). So Turkey has to reduce this energy dependency, and renewable energy sources could be an alternative solution at this point. Because Turkey has a huge potential for renewables, especially in solar and wind energy. The aim of this paper is to emphasize the importance of solar and wind energy in terms of employment opportunities for Turkey, given that the number of unemployed persons aged 15 years old and over is about 4 million 468 thousand persons in the period of January 2019 and that the total installed capacities are 3,4 GW and 6,5 GW in these sectors.
\end{abstract}

\section{Introduction}

Turkish economy has achieved a good performance with its steady growth since 2006. It's growth rate was 5,7\% on average in the period of 2006-2017 and this growth rate has reached $7,4 \%$ in 2017 . Within this particular field Turkish economy has come to the forefront among OECD countries. Although this spectacular growth performance, Turkish economy has failed to reduce the unemployment rates. For example, the unemployment rate is $9,9 \%$ on average for this period. Especially the youth unemployment rate is more apparent. It's been nearly for two times higher than overall unemployment rates (19,3\% on average), or in other words, young people are nearly three times more likely to be unemployed in Turkey. Figure 1 shows this “jobless economic growth" for the period of 2006-2017.

\footnotetext{
${ }^{1}$ Dr. Öğr. Üyesi, Aksaray Üniversitesi
} 
Figure 1: The Unemployment, Youth Unemployment and Growth Rates in Turkey, 2006-2017 (\%)

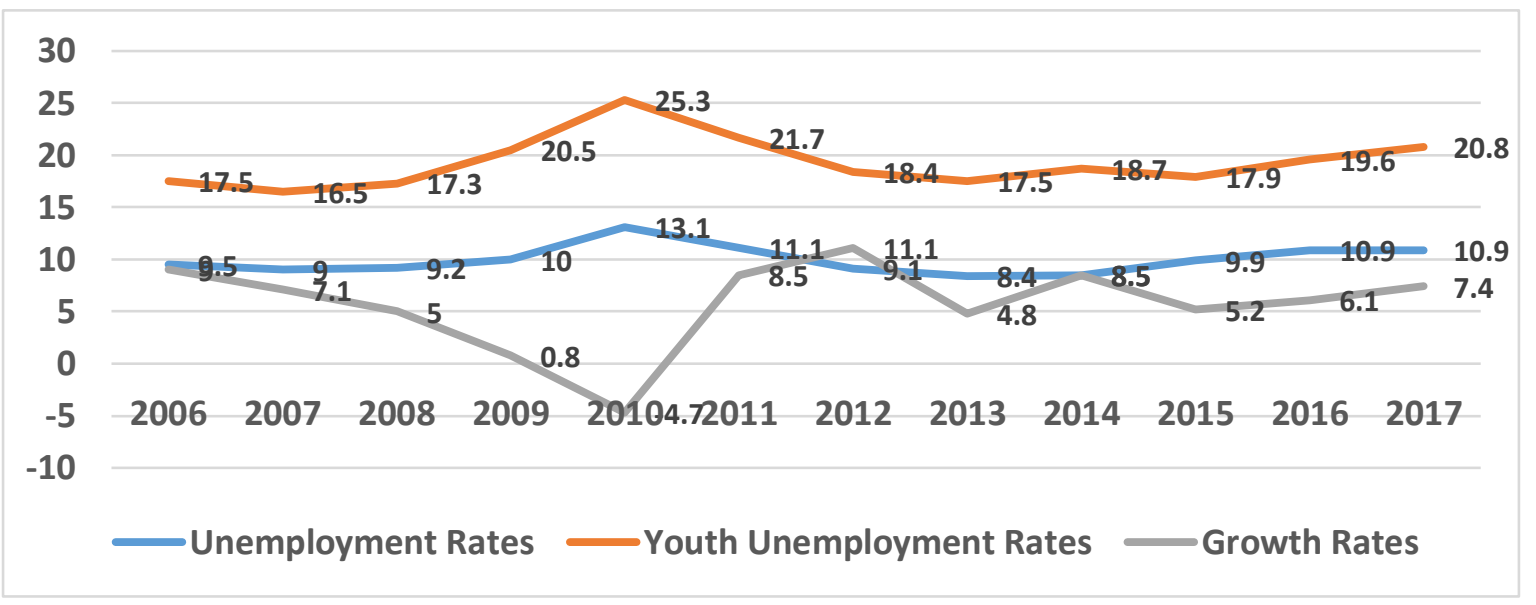

Source: Turkish Statistical Institute (TSI) database.

As seen from Figure 1, Turkish economy has grown steadily but the unemployment rates didn't fall below 10\% generally (and 20\% for youth) and the number of unemployed persons aged 15 years old and over is about 4 million 468 thousand persons in the period of January 2019. Moreover unemployment rates in Turkey has been on an upward trajectory since 2012 and OECD projections suggest that Turkey's unemployment rate is likely to remain above $10 \%$ through to the end of 2018 (OECD, 2017).

On the other hand this high growth rates have been major drivers of energy demand in the Turkish energy market. According to Turkey Review 2016 by International Energy Agency (IEA) energy supply in Turkey has been on an upward trend for the last four decades to meet the rapidly increasing energy needs of the fast growing economy (IEA, 2016). For example, while Turkey's total primary energy supply (TPES) was 129,7 million tonnes of oil-equivalent (Mtoe) in 2015, representing an increase of 54\% from 84,2 Mtoe in 2005, electricity demand almost doubled to reach 207 terawatthours (TWh) in 2015, while gas demand grew even faster, rising from 22 billion cubic metres (bcm) to $49 \mathrm{bcm}$ for the 2005-2015 period ${ }^{2}$ (IEA, 2016, pp. 9-22).

And this growing energy demand has been met by rising energy import as only $22.5 \%$ of energy supply is met by domestic production. Figure 2 reflects the dependency rate on energy imports

\footnotetext{
${ }^{2}$ For a ecological perspective for energy and enviromental problems in Turkey see. Yayla, 2014.
} 
in Turkey from 2006 to 2015 . The dependency rate on energy imports in Turkey reached $77.5 \%$ by 2015 .

Figure 2: Dependency on Energy Imports in Turkey, 2006-2015

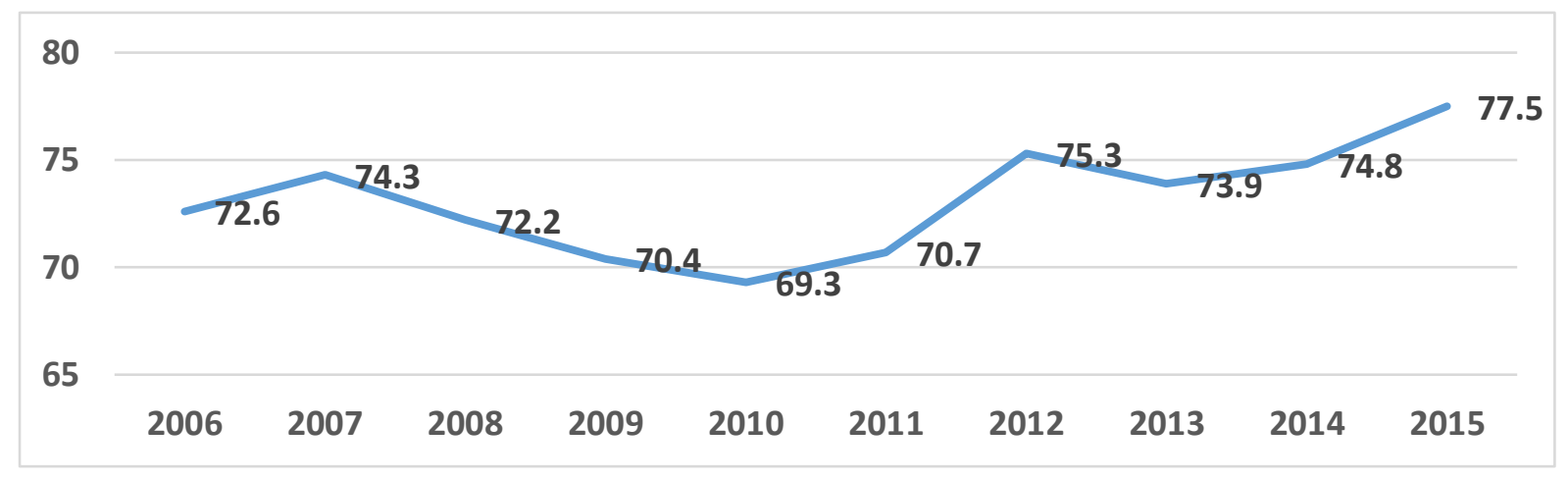

Source: https://www.statista.com/statistics/691224/dependency-on-energy-imports-in-turkey/.

Natural gas was the main fuel in Turkey, accounting for 30,2\% of total primary energy supply (TPES) and 38,6\% of electricity generation in 2015. Natural gas supply was almost entirely provided by imports of 48,2 billion cubic metres ( $\mathrm{bcm}$ ), as domestic gas production is negligible $(0,4 \mathrm{bcm})$. Since 2005 , Turkey's natural gas net imports have grown by almost $80 \%$ and total imports in 2015 were 48,2 bcm, originating mostly from the Russia (55,1\% of the total), Iran (16,2\%), Azerbaijan (12,3\%), Algeria (8,1\%), Nigeria (2,9\%) and others (IEA, 2016, pp. 103 104).

In 2015, oil was the second-largest energy source $(30,1 \%)$ in Turkey, just behind natural gas $(30,2 \%)$ and followed by coal $(27,3 \%)$. Over the last decade, net crude oil imports have increased by $7,2 \%$, while net imports of oil products have grown by $260 \%$. Turkey has become a major export market for oil products from the Middle East, while crude oil supplies from the Russia, Iran and Libya collapsed [2]. However, most of the hard coal consumed in Turkey has to be imported, as domestic coal is low quality and lignite fields are only partially developed [2]. So it could be said that Turkey depend on import with regard to primary energy supply. Table 1 shows that Turkey's oil, gas and coal dependency on imports. 
FSECON BILIR, H. (2019), "Solar and Wind Energy: An Alternative Solution for the Problem of Jobless Economic Growth in Turkey", Fiscaoeconomia, Vol.3(3), 110-130.

Table 1: Turkey's Oil, Gas and Coal Dependency on Imports, 2016

\begin{tabular}{|l|l|l|}
\hline FUEL & Quantity & Import/Export Country \\
\hline Crude Oil & $25.1 \mathrm{Mt}$ & Iraq (36.9\%) \\
Imports & $0.6 \mathrm{Mt}$ & Singapore (31.3\%) \\
\hline Oil Products & $24.9 \mathrm{Mt}$ & Russia (23.5\%) \\
Imports & $5.8 \mathrm{Mt}$ & Egypt (19.6\%) \\
\hline Exports & $46.3 \mathrm{bcm}$ & Russia (53\%) \\
\hline Natural Gas & $0.7 \mathrm{bcm}$ & Greece (100\%) \\
\hline Exports & $3.2 \mathrm{TWh}$ & Colombia (42.7\%) \\
\hline Coal & $36.2 \mathrm{Mt}$ & Not specified (100\%) \\
\hline Exports & $0.1 \mathrm{Mt}$ & $88.2 \%)$ \\
\hline
\end{tabular}

Source: IEA, 2016.

In this direction, energy import is the main chapter in Turkey's import. For example, Turkey's energy import is $\$ 37,2$ billion, while total import is $\$ 233,7$ billion, so the percantage of energy import in Turkey's total import is $15 \%$. Figure 3 indicates that this ratio has always been above $13 \%$. 
Figure 3: Turkey's Total Import and Energy Import, 2006-2017

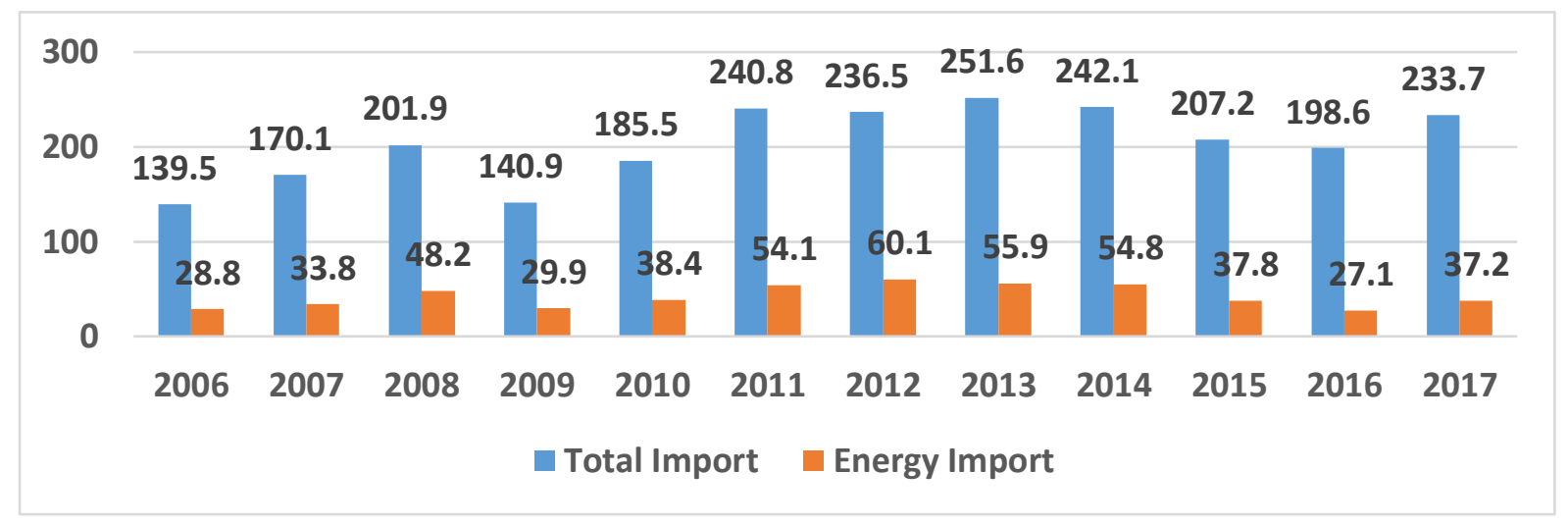

Source: TSI database.

So one of the most crucial problems for Turkey is energy dependency and Turkey has to get rid of this energy dependency to create employment. Because the production structure depends on import and Turkey has difficulties to create new employment opportunities. Renewable energy sources may be a solution at this point. The term of renewable energy, in a broad sense, refers to biomass energy, hydro energy, solar energy, wind energy, geothermal energy, and ocean energy (Turkenburg, 2012, p. 773). Renewable energy is being used increasingly in power generation, heating and cooling nowadays, and transport. However renewable energy sources will be discussed only in the context of power generation and creating employment. Besides that renewable energy sources will be examined within the scope of solar PV and wind power as both Turkey has huge potential in terms of these sources, and they're rising investment and employment areas in Europe and in the emerging markets such as China, India and Brazil.

In this direction, firstly the general outlook of renewable energy in the world will be examined, and then recent developments in renewable energy sources in Turkey will be discussed. And lastly the employment opportunities of renewables for Turkey will be evaluated.

\section{Renewable Energy Sources: Turkey's Outlook from a Global Perspective}

Primary energy demand and consumption has grown for a long time in the world. According to BP's Statistical Review of World Energy, world primary energy consumption reached 13.276 million tons of oil equivalent (toe) in 2016 and it's average annual growth rate is $1,8 \%$, while this rate was $1 \%$ in 2016. Similarly primary energy consumption has reached from 95,8 Mtoe to 137,9 Mtoe in this period (BP, 2017, p. 8) 
Figure 4: World Primary Energy Consumption (Mtoe)

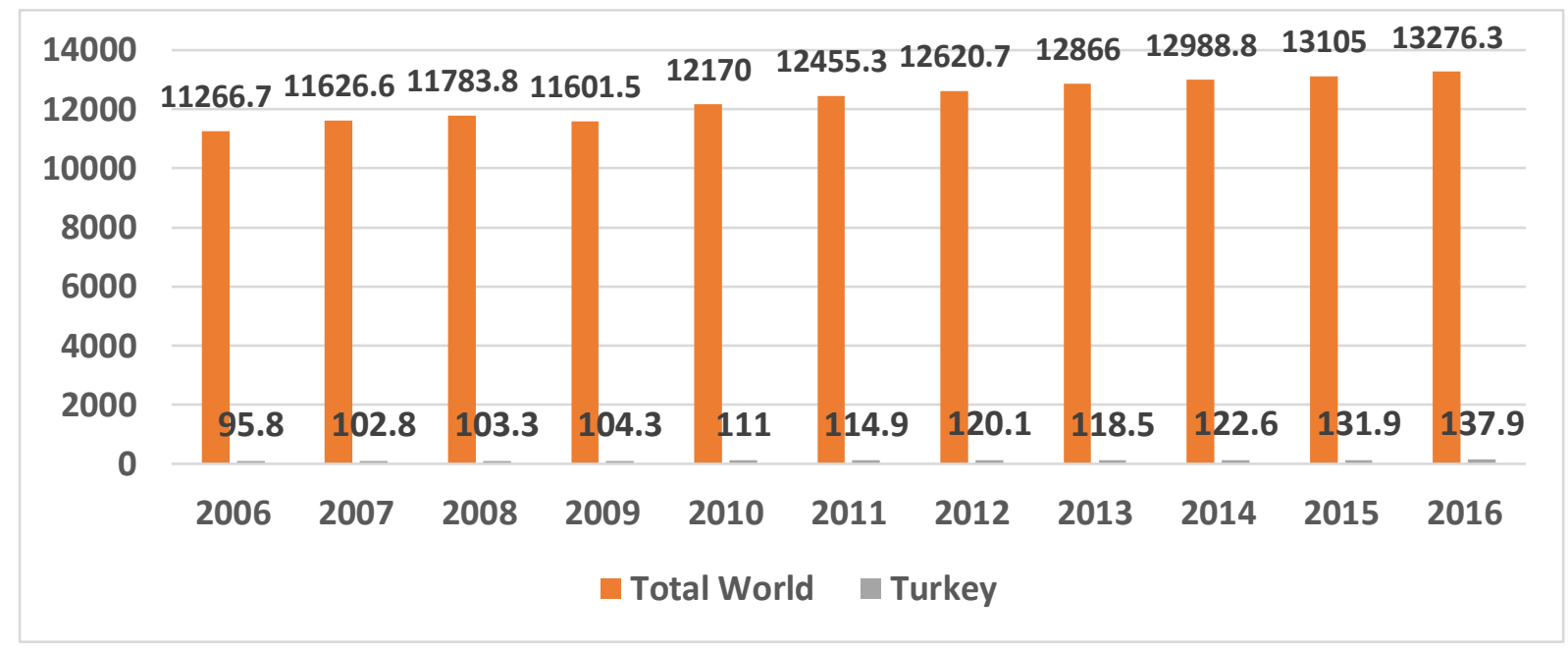

Source: BP, 2017, p. 8.

And this growing energy demand has rised the importance of renewable energy sources in the whole world. Because traditional baseload generators such as coal and nuclear power plants are beginning to lose their economic advantage and may no longer be the first to dispatch energy ${ }^{3}$ (REN21, 2017, p. 27). In this direction renewable energy installed capacity has grown since 2007 both in the world and in Turkey. According to the International Renewable Energy Agency (IRENA) database, total installed capacity was $2.179 \mathrm{GW}$ in 2017, while $992 \mathrm{GW}$ in 2007 in the world.

\footnotetext{
${ }^{3}$ In this context, some studies suggest that $75-95 \%$ or even $100 \%$ contributions from renewables can be achieved by 2050 regionally (in the European Union (EU), for instance) as well as (Greenpeace and EREC, 2007, 2010; Krewitt vd., 2009; ECF, 2010; WWF, 2011).
} 
Figure 5: Trends in Renewable Energy in the World, 2007-2017 (Installed Capacity, MW)

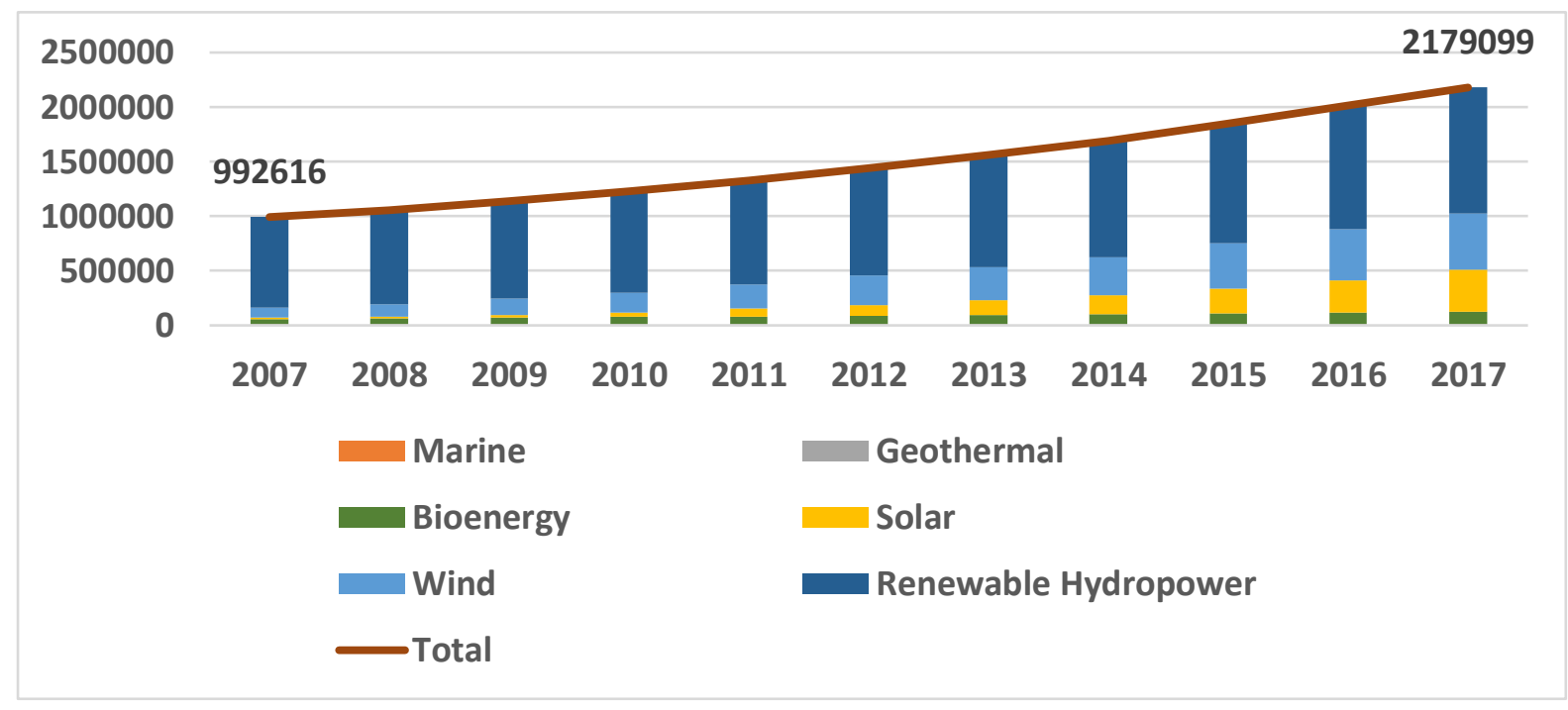

Source: IRENA database.

Similarly total installed capacity in renewable energy reached to $38,7 \mathrm{GW}(11,4 \mathrm{GW}$, excluding hydropower), while 13,6 GW (260 MW, excluding hydropower) in 2007 in Turkey. According to IEA renewable sources constituted $48,9 \%$ of all domestic energy production, with biomass providing $10,1 \%$, hydro $17,9 \%$, geothermal $14,8 \%$, solar $3 \%$ and wind $3,1 \%$. And energy from renewable sources represented $12,1 \%$ of TPES, and came from biofuels and waste $(2,5 \%)$, hydro $(4,4 \%)$, geothermal $(3,7 \%)$, solar $(0,7 \%)$ and wind $(0,8 \%)$ (IEA, 2016, p. 23$)$. 
Figure 6: Total Renewable Energy Installed Capacity in Turkey, 2007-2017 (MW)

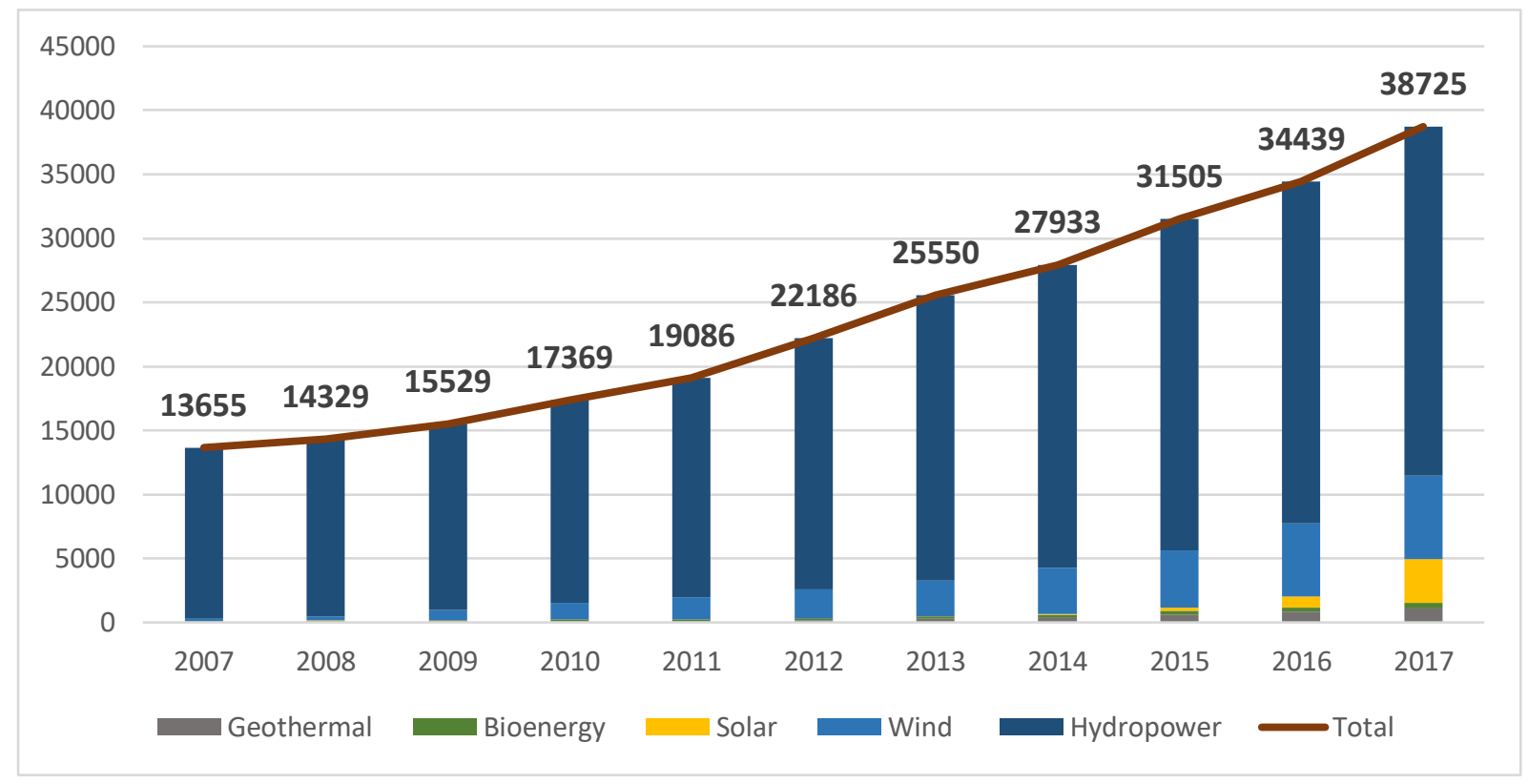

Source: IRENA database.

On the other hand, solar and wind energy have upward trend and total installed capacity for solar and wind power has grown \%800 over the last decade, reaching to $904,5 \mathrm{GW}$ as seen from Figure 5. Correspondingly solar PV was the world's leading source of additional power generating capacity in 2017, raising nearly $\% 30$ to $390,6 \mathrm{GW}$. In solar PV the top five markets are China (130,6 GW), Japan (48,6 GW), United States (42,8 GW) and Germany (42,3 GW) and these countries accounted for about $77 \%$ of total installed capacity. The other top countries are Italy (19,6 GW), India (19,2 GW), United Kingdom (12,7 GW), France (8,1 GW), Spain $(7,2 \mathrm{GW})$ and Australia $(6,4 \mathrm{GW})^{4}$. On the other hand, according to IEA at least 17 countries had enough solar PV capacity in 2017 to meet $2 \%$ or more of their electricity demand, and several countries met far higher shares during 2016, including Honduras $(9,8 \%)$, Italy $(7,3 \%)$, Greece (7,2\%) and Germany (6,4\%) (IEA, 2017, p. 23).

\footnotetext{
${ }^{4}$ Also considering solar thermal technology which is used extensively in all regions of the world to provide hot water, to heat and cool space, to dry products and to provide heat, steam or refrigeration for industrial processes or commercial cooking, the top five countries for cumulative capacity were China, the United States, Turkey, Germany and Brazil in 2015 (REN21, 2017, p. 75).
} 
Figure 7: Solar Energy Global Cumulative Capacity, 2007-2017 (GW)

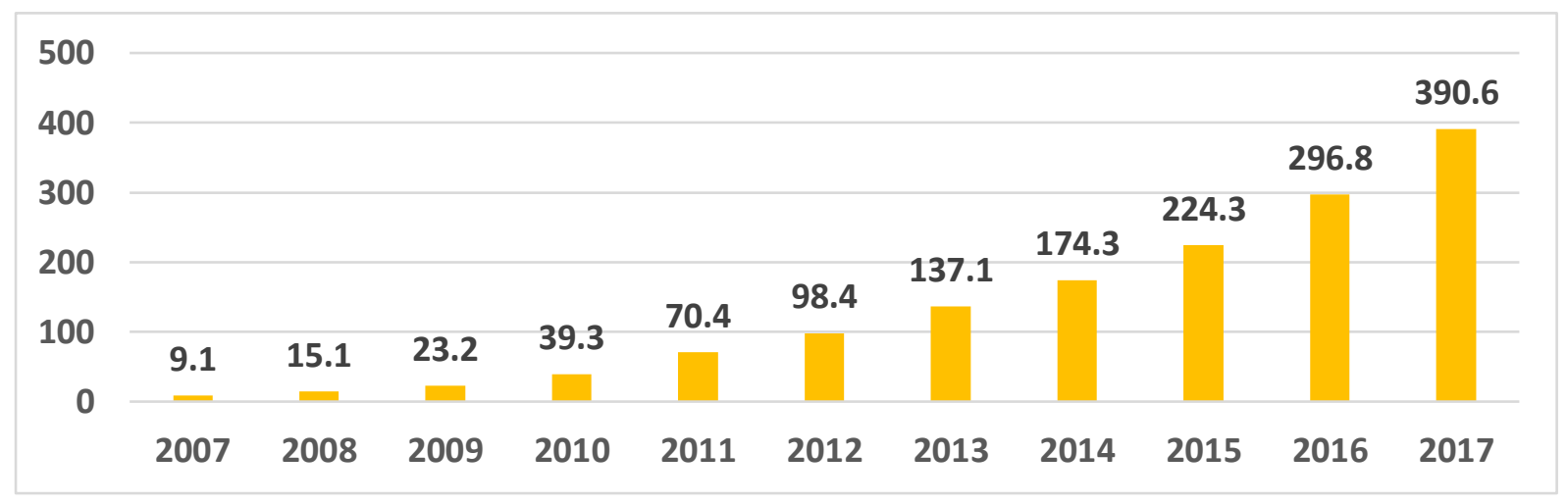

Source: IRENA database.

Turkey's total solar power installed capacity has grown since 2013. According to IRENA databese, total installed capacity for solar power was $3,4 \mathrm{GW}$ in 2017 , while it was $3 \mathrm{MW}$ in 2007. In this regard, Turkey's ranked as the thirteenth for cumulative capasity in the world.

Figure 8: Total Solar Power Installed Capacity in Turkey, 2007-2017 (MW)

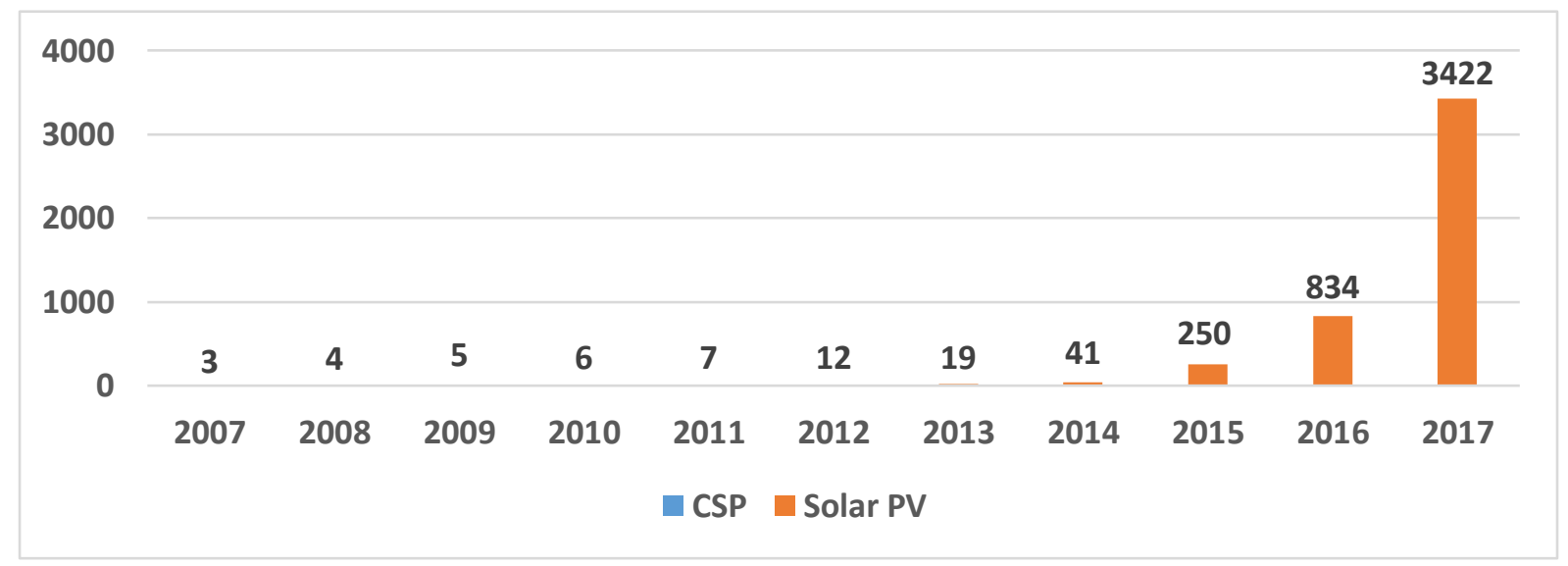

Source: IRENA databese.

So Turkey has seen a significant increase in solar energy cumulative capacity over the last decade, but this increase isn't sufficient. Because Turkey has a great potential for renewable energy resources, notably in solar and wind power ${ }^{5}$. For example, Turkey is in the forefront with regard to solar energy potential among the OECD and EU countries. The average sunshine

\footnotetext{
${ }^{5}$ For studies estimating Turkey's renewable energy potentials see Çapik, Yılmaz and Çavuşoğlu, 2012; Toklu 2013, 2017; Melikoglu, 2016, 2017.
} 
duration and the solar radiation in Turkey are $7.2 \mathrm{~h} /$ day and $309.6 \mathrm{cal} / \mathrm{m} 2 \mathrm{day}$, respectively. The South-East Anatolia and Mediterrian regions are particularly rich in solar energy sources. In this context, the president of the International Solar Energy Society Turkey Section (ISES) Kemal Gani Bayraktar stated that Turkey's solar potential for electricity production is estimated as at least $500 \mathrm{GW}$ (Bayraktar, 2016, p. 50).

Figure 9: Solar Energy Potential Atlas of Turkey

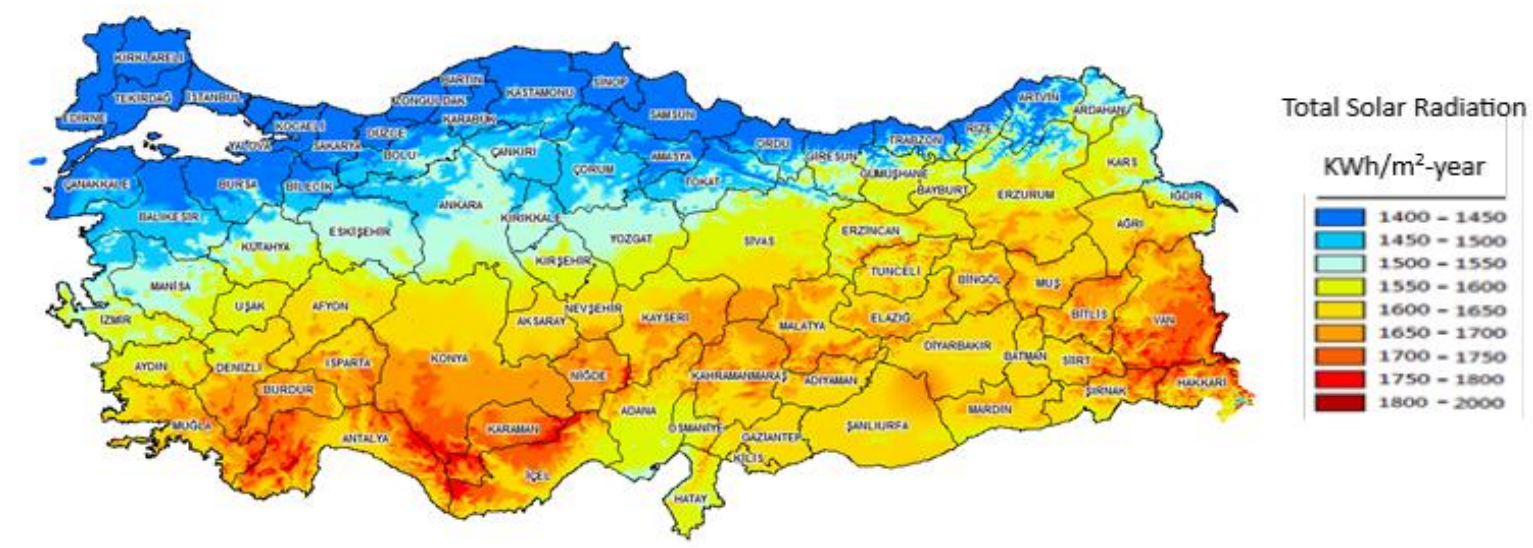

Source: The General Directorate of Renewable Energy (GDRE), http://www.yegm.gov.tr/MyCalculator/Default.aspx.

Accessed: 03.04.2018.

As to wind power, almost $47 \mathrm{GW}$ of wind power capacity was added in 2017 which increased the global cumulative capasity nearly $\% 10$ to 514 GW. Hence, according to IEA, over 90 countries had seen commercial wind power activity, and 29 countries had more than $1 \mathrm{GW}$ in operation in 2016, so wind has become the least-cost option for new power generating capacity in an increasing number of markets. The leading five countries in wind power are China (164 GW), the United States (87,5 GW), Germany $(55,8 \mathrm{GW})$, India $(32,8 \mathrm{GW})$ and Spain $(22,9$ GW). The top other countries were United Kingdom (20,4 GW), France (13,1 GW), Canada $(12,3 \mathrm{GW})$, Brazil (12,2 GW) and Italy $(9,6 \mathrm{GW})$ as wind energy cumulative capasity. And onshore wind was the most cost-effective option for new grid-based power during 2016 in many markets, including Brazil, Canada, Chile, Mexico, Morocco, South Africa, Turkey, and parts of Australia, China, Europe and the United States (REN21, 2017, pp. 82-85). 
Figure 10: Wind Energy Global Cumulative Capacity, 2007-2017 (GW)

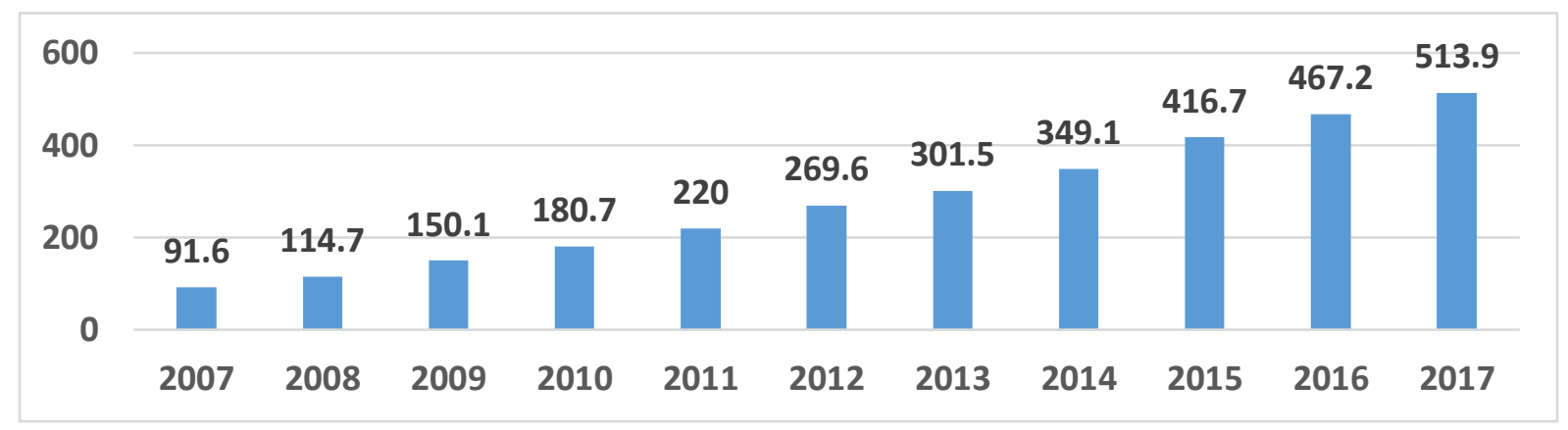

Source: IRENA database.

Turkey has started to utilize its wind potential recently just as solar power, despite its great potential. According to IRENA database, Turkey's wind power total installed capacity has grown from $59 \mathrm{MW}$ to 6,5 GW between the period from 2006-2017. In this context, Turkey's ranked as the twelfth for cumulative capasity in the world.

Figure 11: Total Wind Power Installed Capacity in Turkey, 2006-2017 (MW)

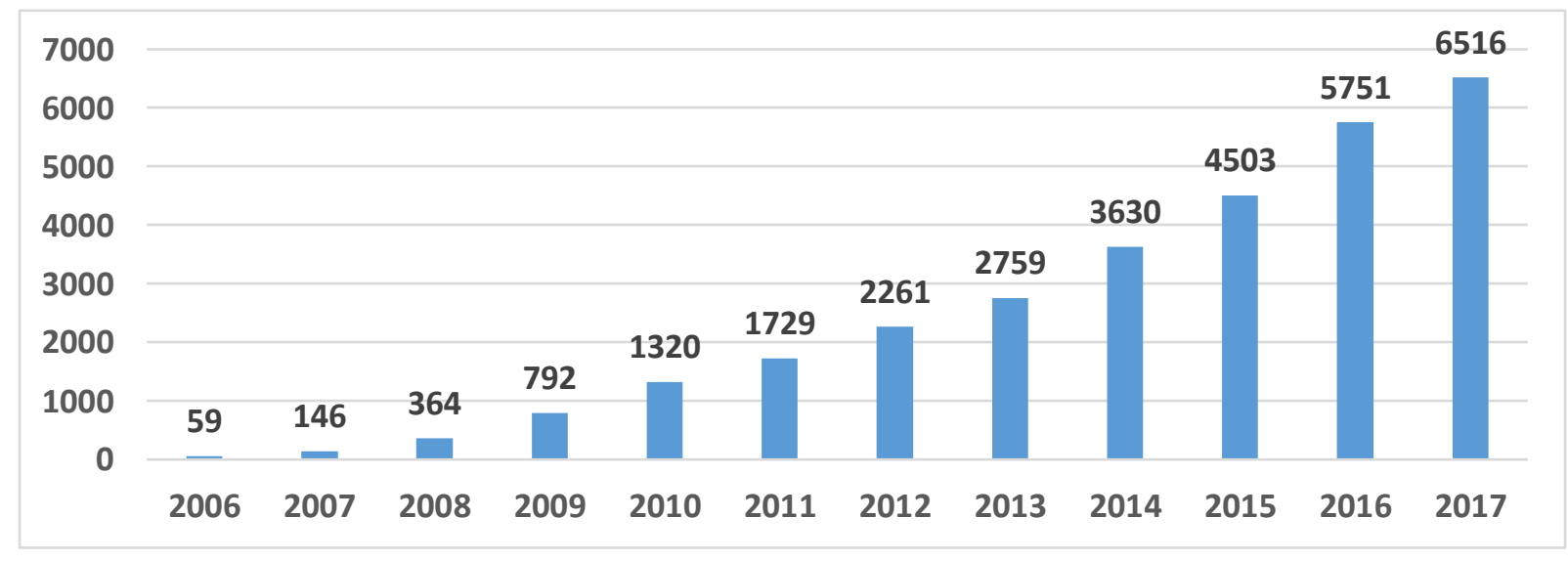

Source: IRENA database.

Furthermore Turkey has huge potential for wind power. Turkey has the first place among the EU countries regarding wind energy potential and also has a great technical wind energy potential of $88 \mathrm{GW}$ (Ugurlu and Gokcol, 2017, p. 150). According to Ministry of Energy and Natural Resources (MENR) wind plants with a capacity of $5 \mathrm{MW}$ can be established in Turkey at heights of 50 meters above ground level, and in areas with a wind speed exceeding $7.5 \mathrm{~m} / \mathrm{s}$. In the Potential Wind Energy Map (PWEM) which sas been prepared in the light of this acceptance, Turkey's wind energy potential is estimated as $48 \mathrm{GW}^{6}$. And the large part of this

\footnotetext{
${ }^{6}$ Further, the offshore wind potential is estimated as nearly $17,4 \mathrm{GW}$ for Turkey according to GDRE.
} 
potential is concentrated in Aegean, Mediterranean and Marmara regions, and Central Anatolia and Central Black Sea regions partly.

Having all these in mind, it could be said that Turkey has experienced strong growth in its total installed solar and wind power capacity, adding almost 9,8 GW between 2007-2017. Clearly, as Ugurlu and Gokcol (2017, p. 157) stated, the renewable energy law in 2005 that includes some legal regulations, developments and important incentives to take private sector's attention to this sector has an important role in this increase in the renewable energy utilization in Turkey over the last decade. In this respect, Turkey has seen increasing investment in renewable energy industry and especially 2015 was a fascinating year in terms of new investments. For example, Turkey's new investments in renewables was almost $\$ 1.9$ billion and Turkey was one of the four countries along with England, France and Netherlands passing \$1 billion threshold (Karagol and Kavaz, 2017, p. 19).

Also in 2016, Turkey included a premium of up to $50 \%$ higher tariffs under the country's wind power FIT if all turbine components are made in the country, and adopted a 50\% tariff on solar panel imports. For the first time, a local content requirement also was applied to tender specifications for the Karapinar solar PV project, for which it is anticipated that $75 \%$ of module components will be manufactured locally in Turkey (REN21, 2017, pp. 124-125). And consequently as seen from Figure 12, there has been an upward trend in Turkey's solar and wind power cumulative capacity over the last decade.

Figure 12: Total Solar and Wind Power Cumulative Capacity, 2007-2017 (MW)

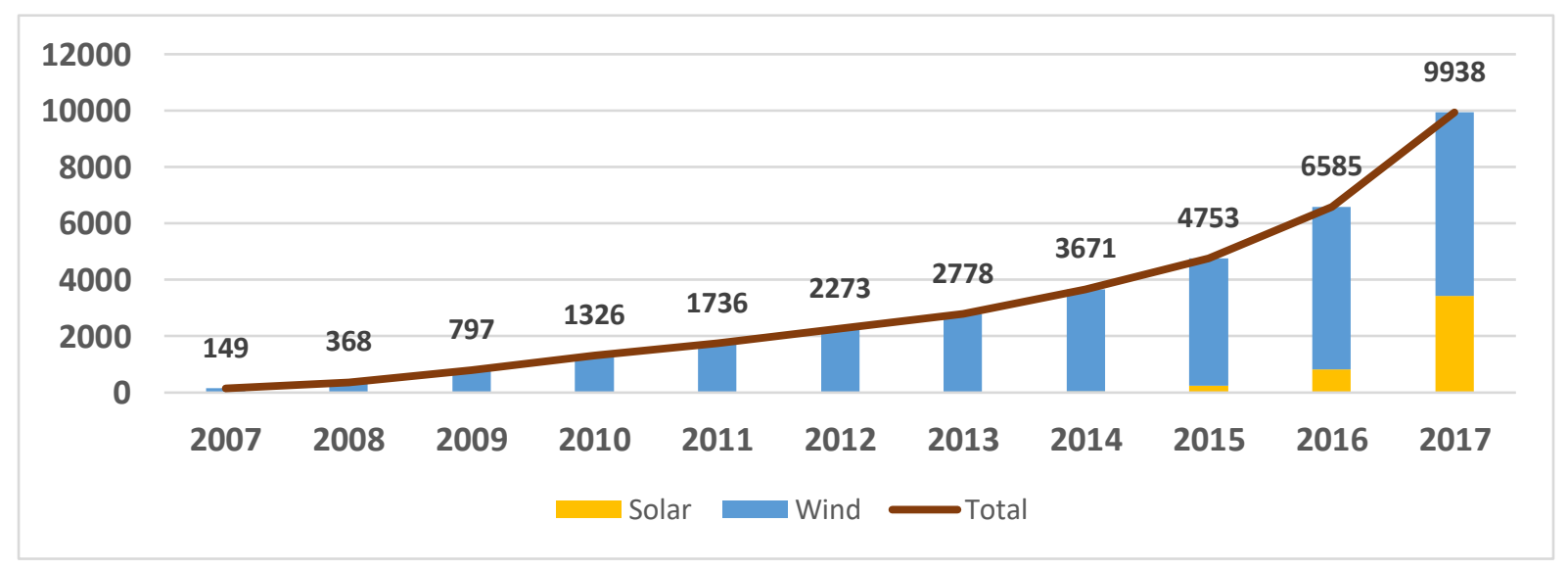

Source: IRENA database. 
Although these remarkeble developments, Turkey is far away from its renewable energy potential. For example, the share of total installed capacity in the total potential is $4 \%$ and $7,6 \%$ for solar and wind, respectively. Therefore new investments and incentives are important for reaching this potential. In this direction, Turkey implemented new energy targets to utilize its renewable energy potential efficiently under the Vision 2023, the year that marks the 100th anniversary of the Republic of Turkey. The energy goals to 2023 include the promotion of indigenous energy resources, such as coal (lignite) and a 30\% share of renewable energy in the electricity mix.

Table 2: Targets for Renewable Power Installed Capacity by 2023

\begin{tabular}{|l|l|}
\hline Energy Sources & Targets \\
\hline Bio-Power from Solid Biomass & $1 \mathrm{GW}$ \\
\hline Geothermal Power & $1 \mathrm{GW}$ \\
\hline Hydropower & $34 \mathrm{GW}$ \\
\hline Solar PV & $5 \mathrm{GW}$ \\
\hline Wind Power & $20 \mathrm{GW}$ \\
\hline
\end{tabular}

According to this strategic plan, main targets for renewable energy sources are to reach a total capacity of $61 \mathrm{GW}$ by 2023 and increase installed power generation capacity to $5 \mathrm{GW}$ of solar and $20 \mathrm{GW}$ of wind. And given the targets presented above, the gross electricity generation in 2023 would be $91.800 \mathrm{GWh}$ for hydropower; $50.000 \mathrm{GWh}$ for onshore wind energy; 5.100 GWh for geothermal energy; $8.000 \mathrm{GWh}$ for solar energy; and $4.533 \mathrm{GWh}$ for biomass. All in all, the total gross electricity generation would be $159.433 \mathrm{GWh}$. This quantity represents $37 \%$ of the total forecast consumption in 2023; the commitment of the Government is $30 \%, 127.324$ $\mathrm{GWh}^{7}$ (YEGM, 2014, p. 67).

\footnotetext{
${ }^{7}$ On the other hand, the cost of achieving all the targets in 2023 is estimated to require investment in the renewable energy generation around 80 billion TL ( 6 billion TL/year), which is about 21 billion USD (1,5 billion USD/year) (Ugurlu and Gokcol, 2017, p. 151).
} 


\section{Employment Opportunities in Renewable Energy and Implications for Turkey}

In parallel with growth in renewable energy markets, renewable energy employment expanded during 2017. According to IRENA, global renewable energy employment reached 10,3 million jobs -directly and indirectly- in 2017, adding 500.000 new jobs last year (IRENA, 2018, p. 3).

Figure 13: Global Renewable Energy Employment by Technology, 2012-2017 (Million Jobs)

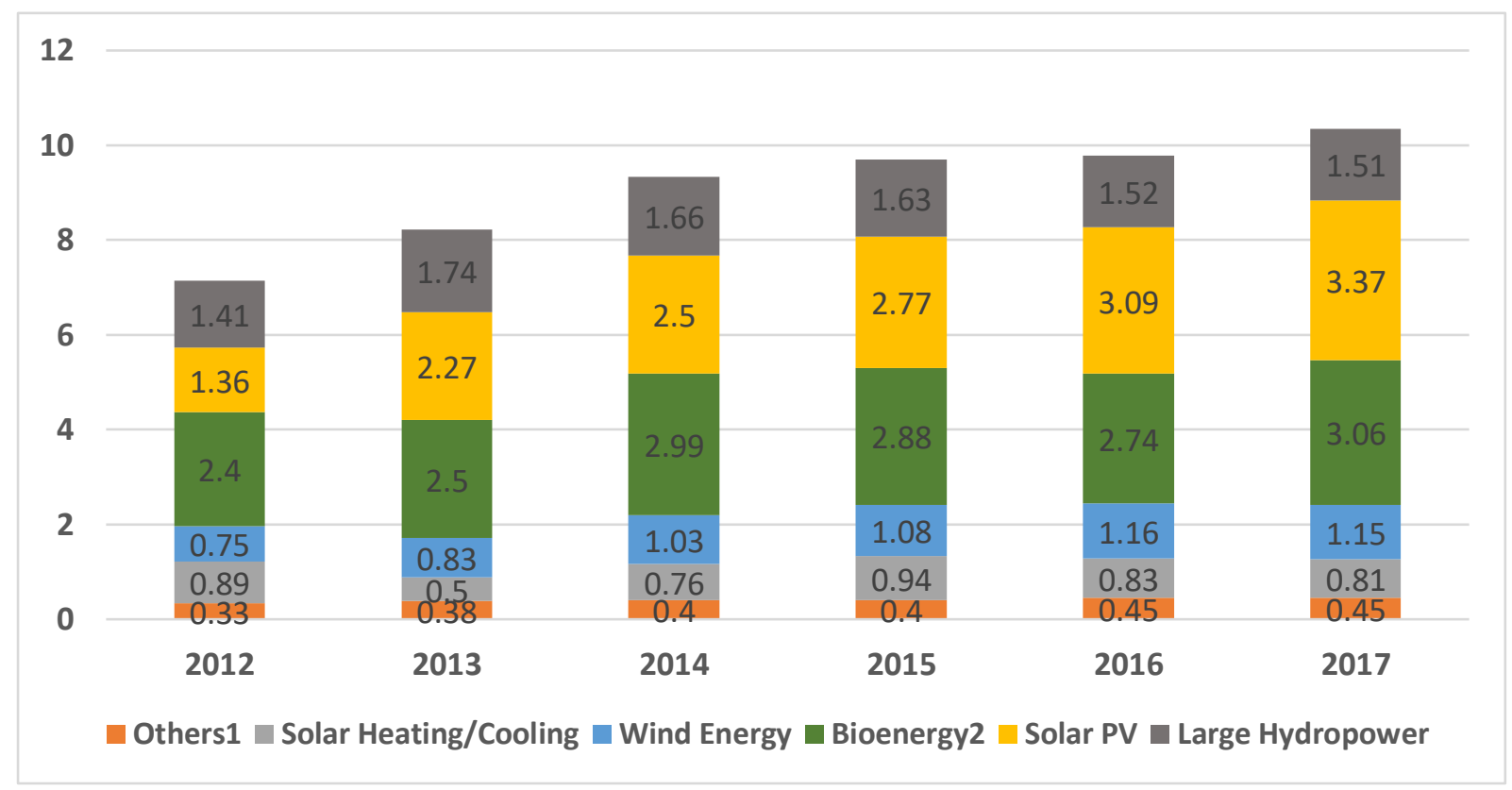

Source: IRENA, 2018, p. 5 .

1 Other technologies include geothermal energy, hydropower (small), concentrated solar power (CSP), heat pumps (groundbased), municipal and industrial waste, and ocean energy.

2 Includes liquid biofuels, solid biomass and biogas

The leading countries in renewable energy employment are China, Brazil, the United States, India, Germany and Japan. China which is at the forefront of renewable energy in the world by far, alone accounts for $43 \%$ of all renewable energy jobs. Its share is particularly high in solar heating and cooling (83\%) and in the solar photovoltaic (PV) sector (66\%), and less so in wind power (44\%) (IRENA, 2018, p. 3). 
Figure 14: Renewable Energy Employment by Technology, 2017 (Thousands)

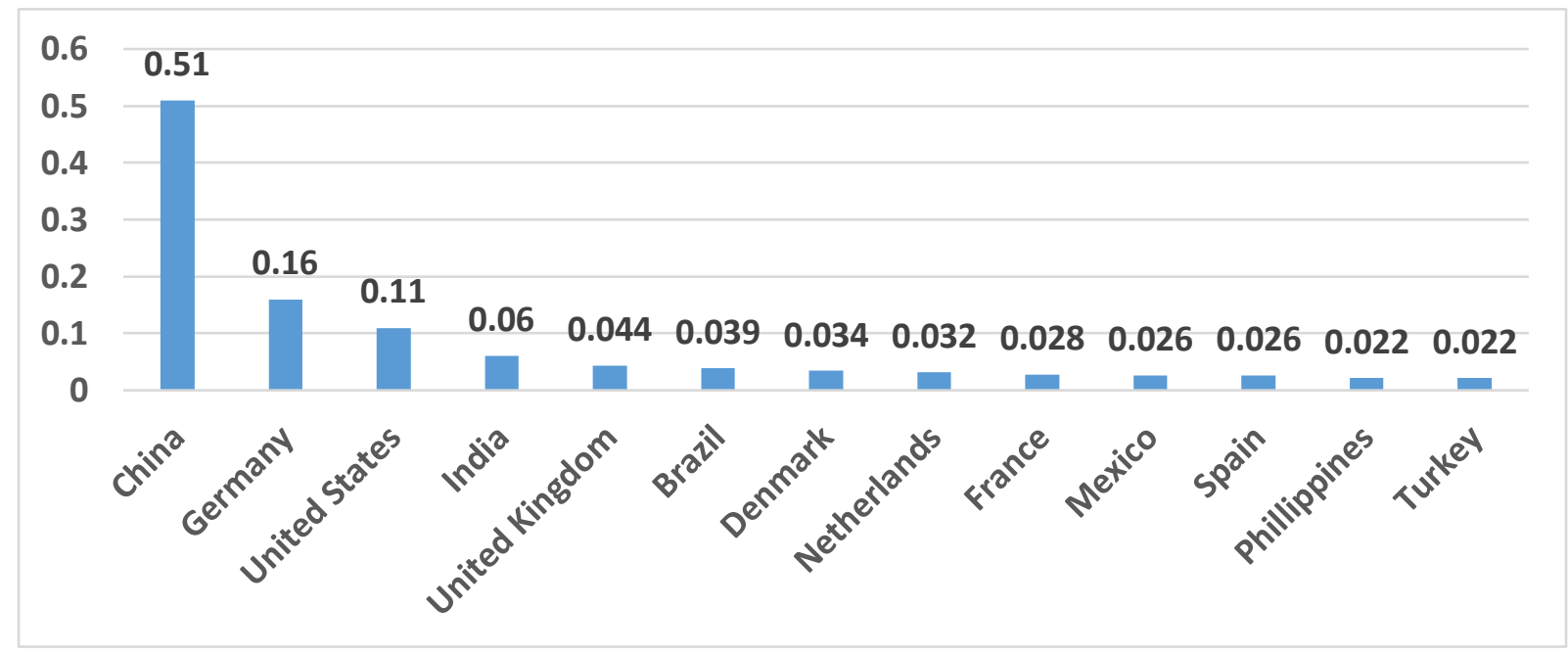

Source: IRENA, 2018, p. 6.

Note: Others includes jobs which are not technology specific.

The new installations in solar PV industry was 94 GW during 2017 and in this direction, the solar PV was the largest employer (almost 3,4 million jobs, up 9\% from 2016). China, India, the United States and Japan were the most important markets, followed by Turkey, Germany, Australia and the Republic of Korea (IRENA, 2018, p. 7).

Figure 15: Leaders in Solar PV Employment, 2017

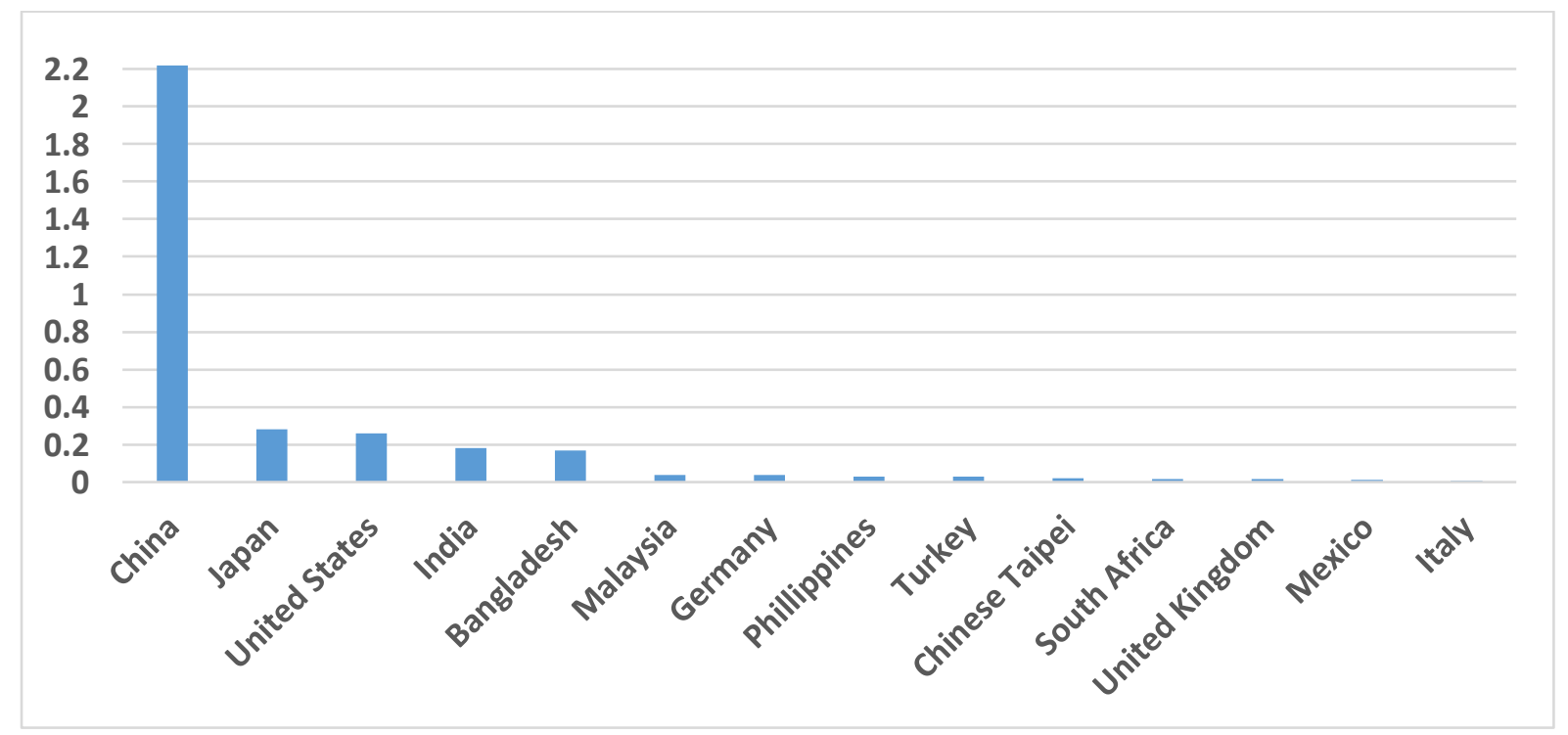

Source: IRENA, 2018, p. 7.

Note: The threshold for inclusion in the figure is 10000 jobs. 
Including its onshore and offshore segments, the wind industry employs 1,15 million people worldwide, a 0,6\% decrease from 2016 and China alone accounts for $44 \%$ of global wind employment. The top five countries represent $76 \%$ of the total (IRENA, 2018, p. 10).

Figure 16: Leaders in Wind Employment, 2017

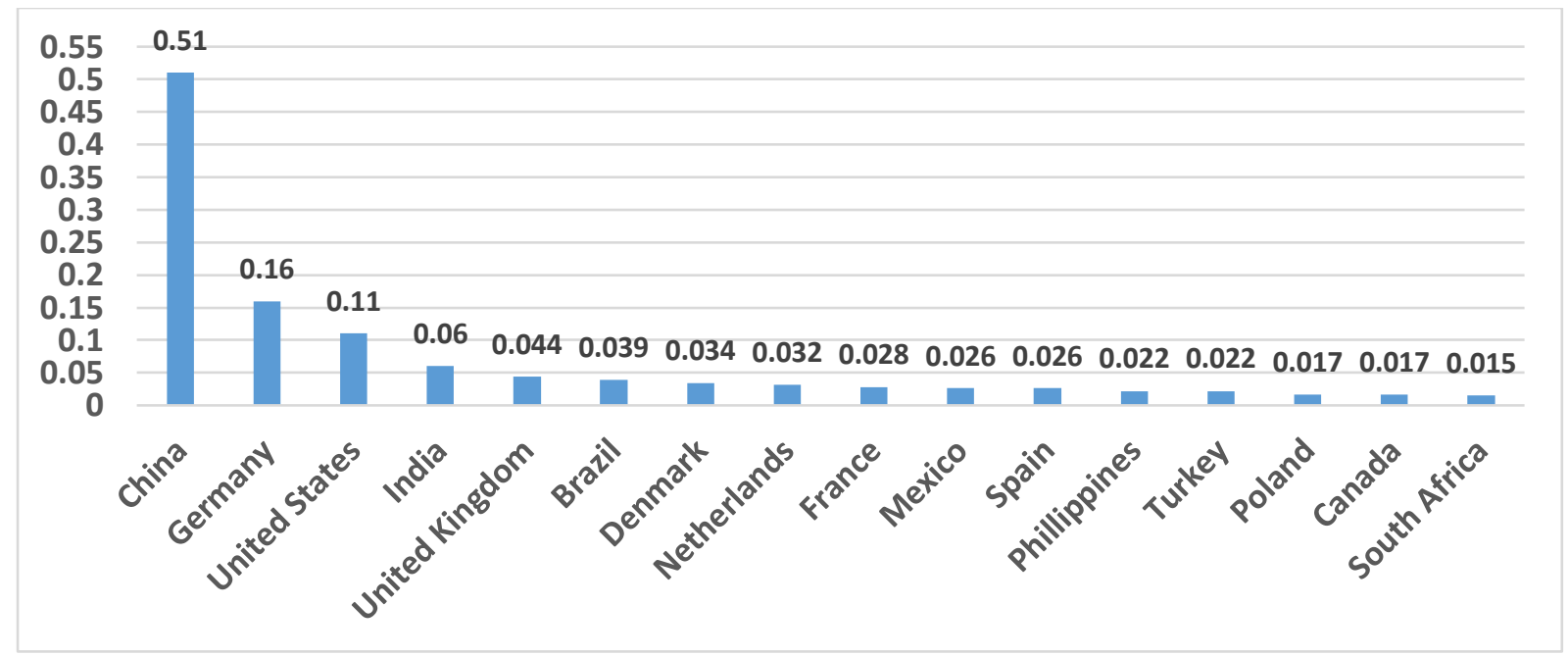

Source: IRENA, 2018, p. 10.

Note: The threshold for inclusion in the figure is 10000 jobs.

As to employment created by renewable energy sources in Turkey, total renewable energy employment was 127.588 in 2016 . According to IRENA databese, wind power industry was the largest employer in 2016, creating 52.886 jobs. Some 30.000 people people were employed in the solar PV and solar heating/cooling industry. Especially Turkey has an estimated 16.600 people working in this sector, behind China and Brazil (IRENA, 2018, p. 11). Figure 17 shows total renewable energy employment in Turkey.

Figure 17: Total Renewable Energy Employment in Turkey, 2016

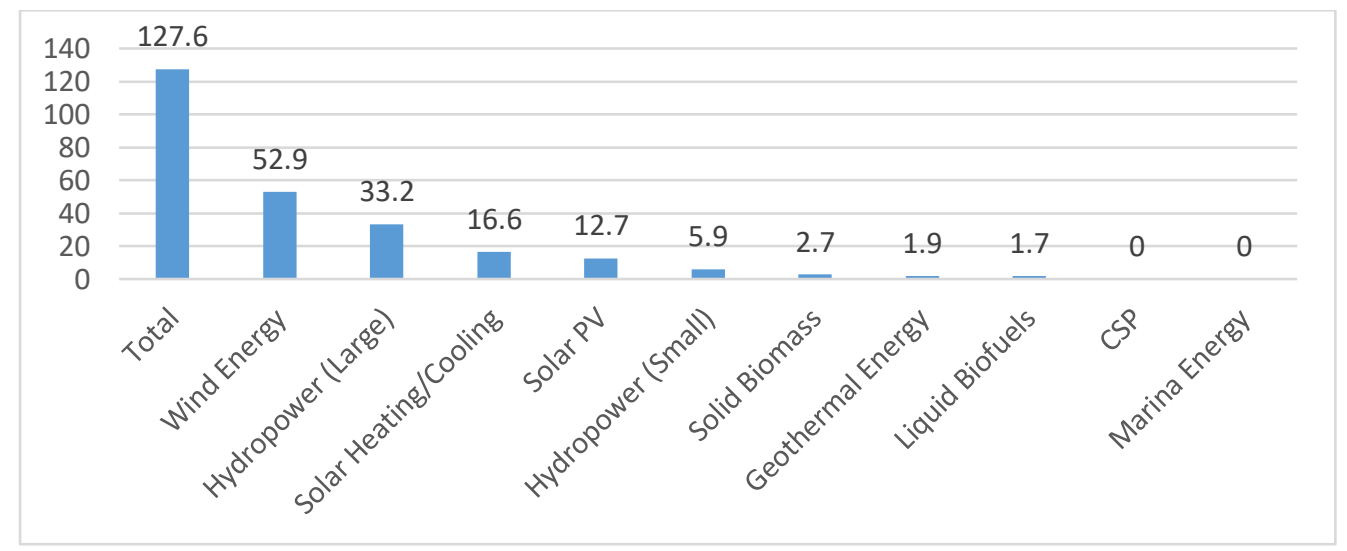

Source: IRENA databese. 
So Turkey started to utilize its renewable energy employment recently and it has a great potential with regard to solution of unemployment issue. The employment potential of renewable energy sources is estimated generally as Direct Employment/Installed Capacity. In this regard, Meyer and Sommer (2014) indicated that PV employment factors in the literature ranged from 28 jobs/MW to 55 jobs/MW depending on the geographical area and wind employment factor ranged from 8 jobs/MW to 13 jobs/MW, while Greenpeace, GWEC and EREC estimated the employment factor (PV, solar heat and solar thermal) as nearly 40 jobs/MW for the solar industry and 27 jobs/MW for the wind industry (just onshore). On the other hand, Cetin and Egritas (2011) accepted the employment factor in the solar industry as 37-46 jobs/MW for Turkey. Greenpeace (2015) estimated employment factors for Turkey as nearly 33 jobs/MW for the wind industry (onshore plus offshore) and nearly 20 jobs/MW for the solar industry, 42 jobs/MW including solar thermal and solar heat sectors for which Turkey has great potential.

In the light of numbers above, the employment factors for Turkey is calculated as nearly 10 (53.000/5.751) and 35 (30.000/834) for the wind and solar industries, respectively. Accordingly, given energy targets for 20.000 MW for wind and 5.000 MW for solar energy under the Vision 2023, potential employment opportunities would be 184.000 and 180.000 in the wind and solar industry, respectively ${ }^{8}$.

Table 3: Projections about Renewable Employment Opportunities

\begin{tabular}{|l|l|l|l|l|}
\hline \multirow{2}{*}{ Energy Sources } & \multicolumn{2}{|l|}{2016} & 2023 \\
\cline { 2 - 5 } & Total Installed & & Total Installed & Estimated \\
& Capacity & Jobs Created & Capacity & Addition Jobs \\
\hline Solar Energy & $834 \mathrm{MW}$ & 29.300 & $5.000 \mathrm{MW}$ & 180.000 \\
\hline Wind Energy & $5751 \mathrm{MW}$ & 52.900 & $20.000 \mathrm{MW}$ & 184.000 \\
\hline
\end{tabular}

\footnotetext{
${ }^{8}$ By the way, Mehmet Özer the CEO of Tunmatik declared that the solar industry has such a potential as to create employment for 300.000 by 2030 in Turkey (https://enerjienstitusu.org/2018/03/05/gunes-enerjisi-sektoru2030da-300-bin-kisiye-istihdam-olusturacak/).
} 
This potential becomes more meaningful given that the number of unemployed persons aged 15 years old and over is about 4 million 468 thousand persons in the period of January 2019 and that the unemployment rate target is $5 \%$ in Vision 2023. Further, as the leading regions are South-East Anatolia and Mediterrian regions for solar power and the Aegean, Mediterranean and Marmara regions, and Central Anatolia and Central Black Sea regions partly for wind power, renewable energy investments could reduce unemployment in different regions, creating new jobs and local employment, especially in rural areas.

\section{Concluding Remarks}

Turkish economy has achieved a good performance with its steady growth over the last decade, but the unemployment rates has remained stable around $10 \%$ for several years. And the main reason of this "jobless economic growth" is the import energy dependency which was $77.5 \%$ in 2015. In this regard renewable energy sources are so important for Turkey. Because Turkey has a strong potential with regard to renewable energy, specifically solar and wind. For example, solar potential for electricity production is estimated as at least $500 \mathrm{GW}$, while wind energy potential is estimated as $48 \mathrm{GW}$ in Turkey. However only about $9 \mathrm{GW}$ is used to generate electricity by 2017 , equal to about $1,6 \%$ of this potential.

And by utilizing this great potential efficiently, Turkey could solve one of the urgent problems: unemployment. For example, total renewable energy employment was 127.588 and specifically almost 30.000 jobs in the solar industry and 52.886 jobs in the wind power industry in 2016 . And given energy goals to 2023, Turkey could create 364.000 more jobs by 2023 .

So Turkey has to develop strategies and policies to increase the renewable share in electricity generation. Firstly Turkey should pay attention to design the renewable energy industry in consideration of international laws and regulations. Emergent markets such as China, India and Brazil and the leading countries in Europe such Germany, France and Denmark may guide Turkey in this regard. Also the education of qualified workers should be improved, promoted the relationship between universities and renewable energy industry and induced private invetsments. IEA recommends, accordingly, that Turkey should remove regulatory barriers to renewables deployment so as to enable investors and other private parties to install renewable energy facilities without undue delay (IEA, 2016, p. 180).

The declining costs and prices especially in solar PV modules can facilitate this process. Because according to REN21, renewables have benefited from a cycle of falling costs spurred 
on by accelerated deployment, and the competiveness of renewable power generation technologies continues to improve around the world [5]. In this direction the solar and wind industry can be competitive with fossil-fired power generation in Turkey.

And IEA confirms that Turkey can increase the share of renewable energy sources. Turkey's renewable energy medium-term outlook is positive. It is the only country in OECD Europe where annual additions of renewables are stable, but growth is behind strong forecasts for many emerging economies (IEA, 2016, p. 177). Similarly the SHURA Energy Transition Centre's comprehensive report reveals that Turkey can double its estimated increase from $20 \mathrm{GW}$ to 40 GW of wind and solar energy by 2026, without any additional cost to the Transmission System Operator's (TSO) investment projections. In other words, doubling Turkey's solar and wind capacity would have no major impact on system planning and operation (SHURA, 2018).

Therefore Turkey has to invest renewable energy sources especially solar and wind to reduce the levels of its import dependence and to provide employment for citizens. Also for the leading regions are South-East Anatolia and Mediterrian regions for solar power and the Aegean, Mediterranean and Marmara regions, and Central Anatolia and Central Black Sea regions partly for wind power, solar and wind energy could be an alternative solution for the issue of jobless economic growth in Turkey creating new jobs and local employment, especially in rural areas.

\section{References}

Bayraktar, K. (2016). “Güneş Ülkemizin Enerji Geleceğidir”. Enerji ve Maden Dergisi, 21, 50-54.

BP. (2017). BP Statistical Review of World Energy: June 2017. https://www.bp.com/content/dam/bp/en/corporate/pdf/energy-economics/statistical-review2017/bp-statistical-review-of-world-energy-2017-full-report.pdf [Accessed 26.09.2018].

Cetin, M. \& N. Egritas (2011). "Employment Impacts of Solar Energy in Turkey”. Energy Policy, 39, 7184-7190.

Çapik, M., A. Yılmaz \& I. Çavuşoğlu (2012). "Present Situation and Potential Role of Renewable Energy in Turkey". Renewable Energy, 46, 1-13.

ECF (2010). Roadmap 2050: A Practical Guide to a Prosperous, Low Carbon Europe. http://elpc.org/wp-content/uploads/2010/04/European-Climate-Foundation_Roadmap2050.pdf [Accessed 05.08.2018].

Greenpeace (2015). Energy [R]evolution: A Sustainable Turkey Energy Outlook. https://www.greenpeace.org/turkey/Global/turkey/report/2015/Energy\%20\%5BR\%5Devolutio n.pdf [Accessed 11.09.2018]. 
Greenpeace \& EREC (2007). Energy [R]evolution: A Sustainable World Energy Outlook. https://www.greenpeace.org/archive-new-zealand/Global/new-zealand/report/2007/1/globalenergy-report.pdf [Accessed 11.09.2018].

Greenpeace \& EREC (2010). Energy [R]evolution: Towards a Fully Renewable Energy Supply in the EU-27. http://www.greenpeace.org/eu-unit/Global/eu-unit/reports-briefings/2010/7/EUEnergy-(R)-evolution-scenario.pdf [Accessed 11.09.2018].

IEA (2016). Energy Policies of IEA Countries: Turkey 2016 Review. https://www.iea.org/publications/freepublications/publication/EnergyPoliciesofIEACountriesT urkey.pdf [Accessed 02.09.2018].

IRENA (2018). Renewable Energy and Jobs: Annual Review 2018. http://irena.org/Imedia/Files/IRENA/Agency/Publication/2018/May/IRENA_RE_Jobs_Annual_Review_2018 .pdf [Accessed 23.12.2018].

Karagol E. \& I. Kavaz (2017). Dünyada ve Türkiye'de Yenilenebilir Enerji. İstanbul: Turkuvaz Yayınc1lik.

Krewitt, W., S. Teske, S. Simon, T. Pregger, W. Graus, E. Blomen, S. Schmid \& O. Schäfer (2009). "Energy [R] evolution 2008: A Sustainable World Energy Perspective". Energy Policy, 37 (12), 5764-5775.

Melikoglu, M. (2016). “The Role of Renewables and Nuclear Energy in Turkey's Vision 2023 Energy Targets: Economic and Technical Scrutiny". Renewable \& Sustainable Energy Reviews, 62, 112.

Melikoglu, M. (2017). "Geothermal Energy in Turkey and around the World: A Review of the Literature and an Analysis based on Turkey's Vision 2023 Energy Targets". Renewable \& Sustainable Energy Reviews, 76, 485-492.

Meyer, I. \& M. Sommer (2014). Employment Effects of Renewable Energy Supply: A Meta Analysis. WWWForEurope Policy Paper, No. https://www.wifo.ac.at/bibliothek/archiv/36286/WWWforEurope_PP_12.pdf [Accessed 19.12.2018].

OECD (2017). Employment Outlook 2017: How Does Turkey Compare? https://www.oecd.org/turkey/Employment-Outlook-Turkey-EN.pdf [Accessed 02.02.2018].

REN21 (2017). Renewables 2017: Global Status Report. Paris: REN21 Secretariat. http://www.ren21.net/wp-content/uploads/2017/06/178399_GSR_2017_Full_Report_0621_Opt.pdf [Accessed 25.01.2019].

Shura (2018). Turkey can Achieve $40 \mathrm{GW}$ Renewables in 2026. https://www.shura.org.tr/wpcontent/uploads/2018/05/SHURA PR09052018.pdf [Accessed 11.03.2019]. 
Toklu, E. (2013). "Overview of Potential and Utilization of Renewable Energy Sources in Turkey". Renewable Energy, 50, 456-463.

Toklu, E. (2017). "Biomass Energy Potential and Utilization in Turkey”. Renewable Energy, 107, 235244.

Tuckenburg, W. (2012). “Renewable Energy.” In T. B. Johansson, A. Patwardhan, N. Nakicenovic and L. Gomez-Echeverri (Eds). Global Energy Assessment: Toward a Sustainable Future (pp. 761900). Cambridge: Cambridge University Press.

Ugurlu, A. \& C. Gokcol (2017). “An Overview of Turkey's Renewable Energy Trend”. Journal of Energy Systems, 1 (4), 148-158.

WWF (2011). The Energy Report: 100\% Renewables by 2050. https://www.ecofys.com/files/files/ecofys-wwf-2011-the-energy-report.pdf $\quad$ [Accessed 13.10.2018].

Yayla, Y. (2014). “Ekolojik Kriz ve Kapitalizmin Yıkıcı Gelişimi: Yolun Sonu mu?” Quo Vadis: Sosyal Bilimler - Artvin Çoruh Üniversitesi Hopa Uluslararası Sosyal Bilimler Konferansı, 15-17 October 2014, Hopa, Artvin.

YEGM (2014). National Renewable Energy Action Plan for Turkey. https://www.icex.es/icex/GetDocumento?dDocName=DOC2015386867\&urlNoAcceso=/icex/ es/registro/iniciar-sesion/index.html?urlDestino=https://www.icex.es:443/icex/es/navegacionprincipal/todos-nuestros-servicios/informacion-de-mercados/estudios-de-mercados-y-otrosdocumentos-de-comercio-exterior/DOC2015386867.html\&site=icexES [Accessed: 10.04.2018]. 